\title{
MICROCREDITING IN THE SERVICE OF THE DEVELOPMENT OF SERBIAN ECONOMY
}

\author{
Veselinovic Branislav ${ }^{1}$ \\ Drobnjakovic Maja $^{2}$
}

\begin{abstract}
The so-called "social economy" presents a correction and amendment to the market economy, primarily in the context of increase in employment opportunities, and consequently economy boost. An important segment of the "social economy" is micro crediting. Similar to the united and harmonious ant colony able to build an entire metropolis, micro companies possess a potential to revive and rebuild the economy and to contribute to the gross domestic product growth. The purpose of this paper is to point to the current state of microcredit industry both in Serbia and in the world and to look at some examples of good practice. The paper takes an empirical approach, based on the comparative method.
\end{abstract}

Key words: micro crediting / self-employment / economic growth

\section{INTRODUCTION}

The first microcredit program was developed by Muhammad Yunus, the professor of economics from Bangladesh. He argued that banking should not strictly be an economic model, whose main goal is generating extra profit, but an economic-

1 The Faculty of Economics and Engineering Management - University Business Academy in Novi Sad, Novi Sad, Cvećarska 2, bveselinovic@fimek.edu.rs

2 he Faculty of Economics and Engineering Management - University Business Academy in Novi Sad, Novi Sad, Cvećarska 2, majadrobnjakovic@fimek.edu.rs 
social model. By making loans available to poor people in distant rural areas, he initiated a revolution in the field of finance. Amounts of those loans were minimal, and granted funds were used for purchase of livestock and tools. Borrowers formed solidarity groups, in which one person guaranteed for another and vice versa. A member's word represented a collateral security. Numerous statistics confirm that, owing to microcredit financing, the global poverty has been reduced. As a result, Muhammad Yunus was awarded the 2006 Nobel Peace Prize. After the success microcredit programs achieved in Bangladesh, they started to be applied in India, Peru, Indonesia, Ghana and other underdeveloped countries around the world.

The development of micro, small and medium enterprises is of utmost importance for industrial restructuring and decentralization of economy. Economic indicators vary from country to country. However, growing unemployment is a common problem. Micro, small and medium enterprises are a driving force of general prosperity. Microcrediting is one of the ways to overcome economy stagnation, through stimulating self-employment. One of the main difficulties prospective entrepreneurs in Serbia are faced with is a difficult access to financial resources, that is, inability to collect necessary initial capital. Regular commercial banks unwillingly place microcredits because start-up businesses are estimated as highly risky, micro clients are not able to provide adequate security and administrative costs of processing those loans are high as compared to the requested amount. However, encouraging experiences of other countries prove that sustainable microcrediting is possible.

\section{UNEMPLOYMENT ACTS AS A BRAKE ON ECONOMIC AND SOCIAL DEVELOPMENT}

The spread of the world financial and economic crisis is a result of high level of interaction and interdependence among national economies. Under the influence of the "mundialisation" process, the mounting crisis spread over the planet easily, quickly and violently, like tsunami. The first to be affected were highly developed countries. However, the crisis spared neither countries in transition nor underdeveloped countries. As a rule, the crisis remains in the most developed countries for the shortest period, while it spends more time in less developed countries in order to stay the longest in economically weakest countries.

One of the most persistent manifestations of every economic crisis is the unemployment. Globally speaking, the highest unemployment growth rate was 
seen among young people, migrants and unqualified people, who most frequently depend on seasonal and temporary, therefore minimally paid jobs. Consequently, they are more vulnerable and subject to the deterioration of living conditions (European Platform against Poverty and Social Exclusion, 2010). Together with the drop of unemployment, the employment structurechanges, that is, the relationship between sectors changes. As a result of the crisis, there is a drop in the employment rate in the social sector (rationalization of public administration and downsizing the bureaucracy) and traditional industrial branches, while, on the other side, there is an increase in the employment rate in private companies and service sector.

Figure 1. Rising Unemployment Rate in Serbia

\begin{tabular}{|c|c|c|c|c|c|c|c|}
\hline Year & 2007 & 2008 & 2009 & 2010 & 2011 & 2012 & 2013 \\
\hline Serbia & $18.1 \%$ & $13.6 \%$ & $16.1 \%$ & $19.2 \%$ & $23.0 \%$ & $23.9 \%$ & $24.1 \%$ \\
\hline
\end{tabular}

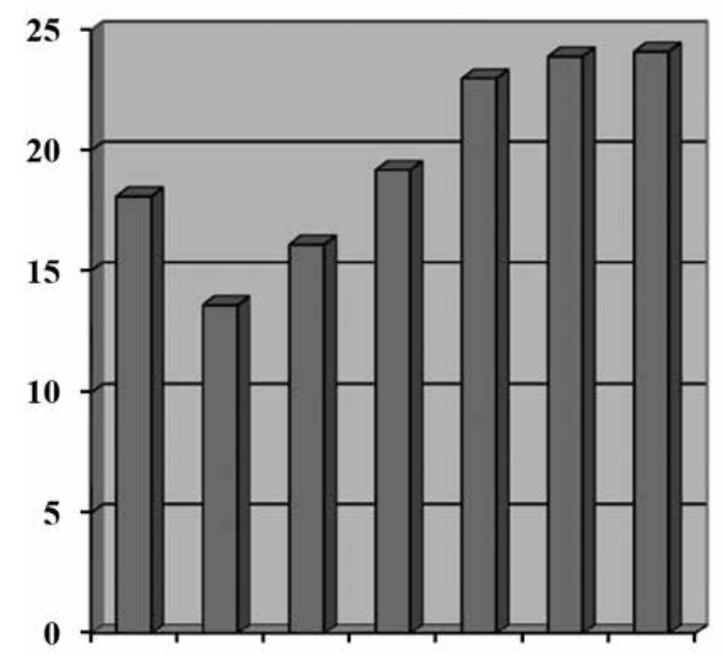

口Serbia Unemployment Rate (\%)

Source: Labour Force Surveys - Serbia (2007-2013). The Statistical Office of the Republic of Serbia.

The severity of the problem becomes obvious when data on the number of employed people are compared - within the period of five years this number is reduced by 268,542, from 2,002,344 in 2007 to 1,733,802 in April 2012 (The Serbian Association of Employers, 2011). Agriculture with forestry and fishing, 
processing industry followed by construction industry were in the most difficult position. Only in these three sectors, cumulatively, over 75.000 jobs were lost. The second category of losers involved micro, small and medium enterprises and entrepreneurs. Within five years, the number of employees in this sector, which was supposed to serve as a buffer to the drop in the employment rate in the period of privatization and economy transformation, fell by more than 230,000 . There are many reasons for this: the crisis of large systems which small business entities were related to, excessive costs of business operations leading to insolvency, and above all, adverse environment for running a business (Labour Force Survey - Serbia, 2012).

Traditional financial institutions also must recognize that they could be unintentionally creating a demand for child labour (financial exclusion of some vulnerable groups) (Frankiewicz, Churchill, 2011, p. 264). A report published in April 2010, "Monitoring Social Inclusion in Serbia - Overview and Current State of Social Inclusion in Serbia", confirmed these negative trends and warns of the need to adopt and implement a consistent policy to combat rising economic and social turbulence. Therefore, economic policy should pay more attention to creating new jobs in small businesses and developing entrepreneurship. Job creation programs have a significant role in achieving employment target of $75 \%$ for 2020 (The Europe 2020 Strategy, The Community of Practice on Inclusive Entrepreneurship).

Microfinance lenders use different approaches to lending, and we have decided to focus on three basic categories. The most-known approach is "group lending," made popular by the "Grameen Bank" of Bangladesh and "BancoSol" in Bolivia. The approach uses self-formed groups of customers that assume joint liability for the repayment of loans given to group members. The second approach is village banking, based on larger groups, but a similar notion of joint liability. The third approach is "individual-based lending", which draws on traditional banking practices and involves a standard bilateral relationship between the bank and customer, absent other interventions (Cull, Demirgüç-Kunt, Morduch, 2007, pp. 4-5). The village banks charge the highest average interest rates and face the highest average costs, due to its specific characteristics (Cull, Demirgüç-Kunt, Morduch, 2007, p. 11). 
Figure 2. Will Microfinance Improve Employment in Serbia?

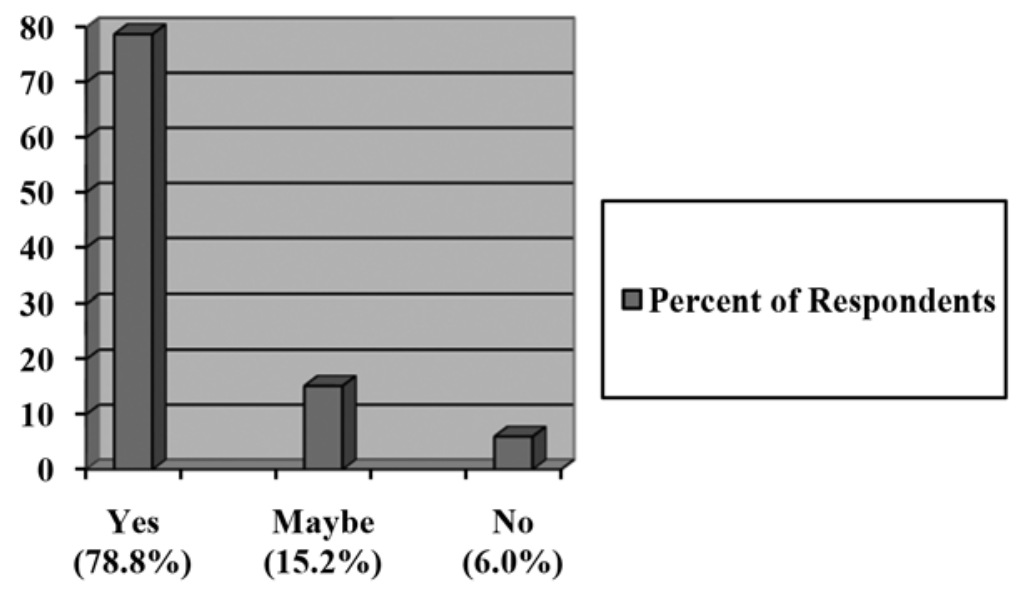

Source: Janićijević, Petković, 2011, p. 142.

Figure 3. Will Microfinance Increase Gross Domestic Product in Serbia?

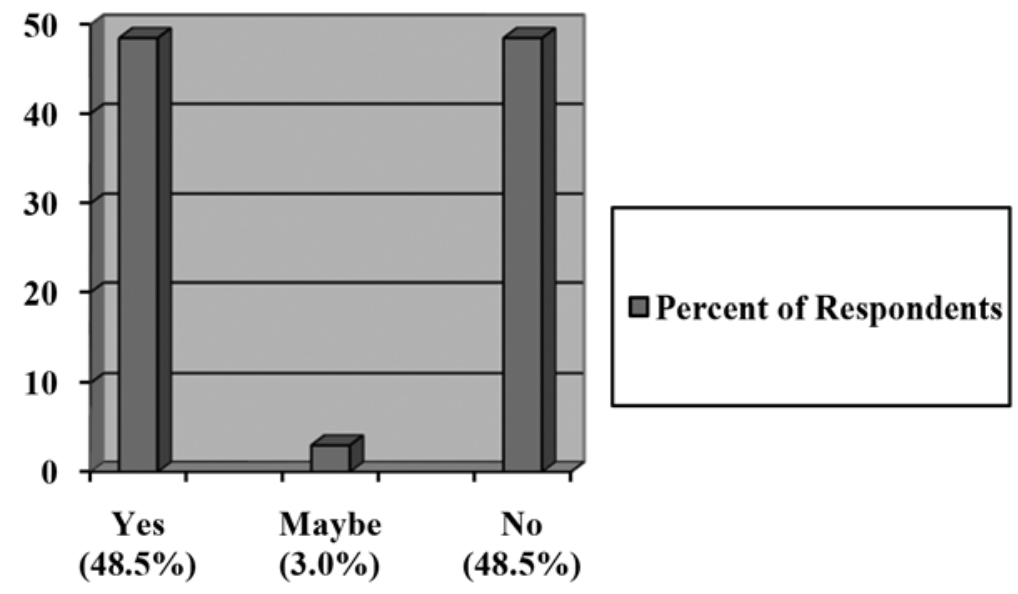

Source: Janićijević, Petković, 2011, p. 142.

Results of the conducted research confirm that financial experts in Serbia (top managers of financial institutions, university professors and people employed in the Government of Serbia) positively assess microfinancing, as a possible way to 
overcome the crisis (employment scope increase and the growth of gross domestic product and competition). For example, microcredit has been a major driver of economic development in Bangladesh ("Next Eleven"). During the last two decades, the promotion of entrepreneurship has become the top priority of public strategies in most countries around the world, regardless of the transition. It reflects an even stronger consensus that the micro, small and medium enterprises sector is primarily responsible for creating new jobs and that entrepreneurial networking is the crucial reaction to the globalization, that is, to accompanying increased uncertainty and complexity. The micro, small and medium enterprises sector is a "missing middle", between industry segments and a so-called "weightless" economy (information and telecommunications technologies sector). The European Union has emphasized the "entrepreneurial cultural" as the key component of competitiveness. The entrepreneurship can boost economic and social cohesion in undeveloped areas, and encourage active engagement of the unemployed and other jeopardized groups of people in current economic and social processes. A highly developed and stable banking sector (equally developed standard banking services and microcredit services) is an essential precondition for reinforcement of entrepreneurship (United Nations Development Programme, MSME Dialogue Series, 2004).

\section{MICROCREDIT MARKET IN SERBIA AND IN THE WORLD}

Microfinancing primarily means the provision of financial services to citizens with lower income, especially the poor (Mahmudul, Islam Rafiqul, 2012, p. 41). The term "microfinancing" is also used in a narrower concept and refers to microcredits aimed at micro-entrepreneurs. In today's world, microfinancing becomes one of the crucial parts of the economic development. Microfinance institutions (MFIs) can be smaller non-profitable, non-governmental or large commercial banks. One of the most important classifications of microfinance institutions is made according to the fact whether they accept deposit or not, which is especially important for national regulators. Presently, there are around 7,000 microfinance institutions in the world, with over 16 million clients. The total turnover is estimated to over 2.5 billion US dollars, with the outstanding growth potential. Microfinancing is a young industry, but with one of the highest growth rates (Fourth Newsletter on Social Inclusion in Serbia, 2010). 
Results of the research conducted in 2007 by the "Entrepreneurial Society Development Centre" from Belgrade confirm that the situation in the microfinance field in Serbia is generally very unfavorable, with an average rate for the five determined criteria (availability, accessibility, acceptability, compatibility and complimentability) just above 2 (on the scale from 1 to 5) (Brkanović, Lalović, Lakić, Tilger, 2007, p. 3). The analysis of granted microcredits shows that the largest number of borrowers are male, which supports the fact that, as far as taking risks and starting up own businesses is concerned, men are bolder and more decisive. In the unemployment structure, most of people deciding to start up their own business are between 41 and 49, followed by people aged 31 to 40 , and the lowest number accounts for people over 50 years of age. Relatively low share of older people is explained by their early retirement or by severance pays obtained for leaving the company. Most commonly, unemployed people opt for starting up small, family companies. Those businesses usually involve processing and sales of meat and fish products, growing fruits and vegetables. Numerous world famous companies, such as Italian "Fiat", started as a family company. As for turnover, out of 100 Italian business groups 40 percent are family firms, whereas in France this percentage amounts to 26 percent, and in Germany it is 17 percent. In Serbia, Arilje is particularly famous for family firms (textile industry).

Regarding loans granted to micro, small and medium enterprises "ProCredit Bank" is one of the most active in Serbia. Their employees work in the field, personally visit clients in order to estimate their needs and repayment possibilities as realistically as possible. They first grant a smaller amount of loan, and then, conditions of giving loans become more favorable with each new loan (Brkanović, 2004). Since 2005, that is, since its entrance into the Serbian market, "Banca Intesa" has had a developed program of microfinancing as an integral part of the corporate philanthropy platform. "Opportunity Bank" is a member of "Opportunity International", a network of banks and microfinance organizations based out of Chicago, which was established in 1971 and is currently active in over 30 countries around the globe. In 2001, "Opportunity International” was awarded a grant from "The United States Agency for International Development" to establish a project to provide financing to micro and small businesses normally excluded from access to banks. The result of this project was “Opportunity Savings Bank", founded in 2002 in Novi Sad. The law on banks in 2006 has closed the category of savings banks and required from all savings banks that wanted to continue their activities in Serbia to transform into commercial banks. This has resulted in the conversion of "Opportunity Savings Bank" into "Opportunity Bank Serbia" in 2007. From inception until end of the second quarter of 2012, "Opportunity Bank Serbia" has made 37.127 loans 
totaling 157.311.792 euros. "Opportunity Bank Serbia" loan portfolio as of end of the second quarter of 2012 was 43.445 .389 euros and number of active loan clients was 12.973. Majority of loans (60\%) are microloans in the amounts up to 5.000 euros disbursed to individual entrepreneurs and small agricultural households, and as much as $56 \%$ of all loan clients are situated in the regions of Central and West Serbia and region of East and South Serbia. Contrary to "Banca Intesa", other banks mostly concentrateon Belgrade and Vojvodina (USAID Serbia). Numerous surveys and studies indicate that microcrediting significantly raised both annual per capita household consumption and the probability of improving housing (roofs). It is also shown that per capita household consumption and the probability of improving the house increased with the frequency of participation. Onetime borrowing has no impact on housing improvements, but it does lead to significant improvements in per capita consumption. Repeat borrowing does matter in both cases (Berhane, Gardebroek, 2011, p. 54).

On the other side, there are three non-bank microcredit institutions in Serbia ("Agro Invest", "Micro-Development Fund" and "MicroFinS") that operate through a local banks. Their operations are focused on rural areas, but have many regulatory and financing difficulties which make their services expensive for clients. According to current Serbian banking law, banks are only financial institutions allowed to engage in acceptance of deposits and granting loans. This type of regulatory approach is a consequence of negative experience from the nineties and number of "Ponzi schemes" that were present on the financial market during that period. These three non-bank microcredit institutions in Serbia had a combined total portfolio of approximately 16.600 .000 euros in loans to over 19.500 borrowers at the end of 2010. In 2011, the major non-bank microcredit institutions in Serbia "Agro Invest" had reported 14.437 active borrowers, of which most (12.867) were farmers (Agroinvest Holding Annual Report 2011). 
Figure 4. Concept of Urban and Rural Microfinance

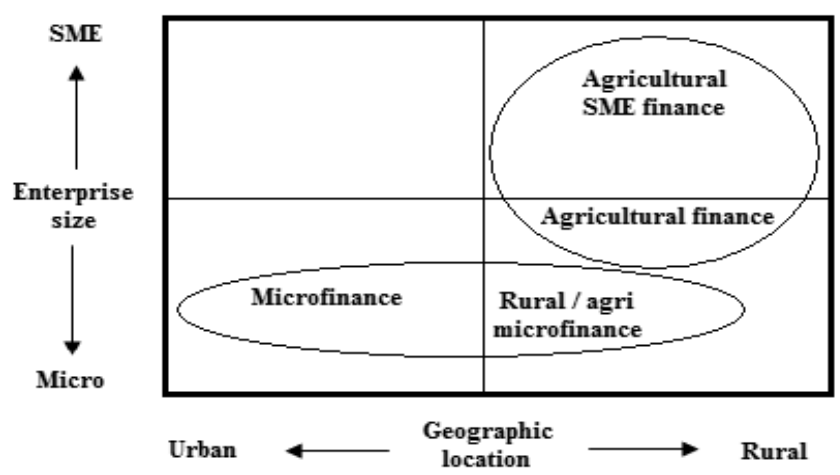

Source: Drobnjaković, 2012, p. 170.

Over the last thirty years, microfinance has had a huge impact on rural development. Nevertheless, the vast majority of poor men and women still do not have reliable, secure ways to save money, protect and build assets. In fact, the most basic formal financial services reach only ten per cent of rural communities. Long term trends in development of Serbian agriculture are determinate with significantly unfavourable economic, security, territorial and political changes (Veselinović, Ševarlić, Nikolić, 2007, p. 622). The past years have proved that commercial banks from all over the world are not willing or able to sufficiently meet the financial needs of rural people, leaving them unserved. Growth of a stable rural financial system, including a variety of financial institutions, platforms and distribution networks, is critical to supporting growth and development in the rural sector. A diverse system can best address demand for financial services beyond credit to include savings, insurance and other products tailored for specific groups, such as rural youth and women. According to the "Civic Initiatives" research, 55\% of respondents said that theywould consider starting their business if the loan terms were more favorable. Survey results also suggest that barriers such as collateral requirements, loan terms and loan size are seen by the youth as major obstacles to financing small business. Most Serbian banks require at least one year of profitloss statement, as well as cash or land collateral, from their borrowers. These requirements, combined with the lack of financial literacy, make it difficult for young entrepreneurs to access commercial loans (Hutchinson, Guttentag, Chen, Mo, 2012). First, from the Serbian banks' perspective, it is too costly to perform the necessary due diligence to assess each loan applicant's risk premium. By way of cost-effectiveness, banks automatically place the highest risk premium to first-time startups, which most youth businesses are. Second, Serbia's low sovereign rating 
(BB-) makes it expensive for banks to borrow euro-denominated funds from the rest of the world. Third, the high reserve requirement set by the National Bank of Serbia that aims at enhancing the overall financial sector's resilience to external shocks further increases the cost of lending for banks. Last, the Serbian financial sector lacks adequate microloan service for startups. The limited amount of microloan products is also attributed to Serbia's legal framework, which currently does not provide a way for non-banking microfinance institutions to administer loans.

Table 1. Ease of access to loans, 1-7 (best)

\begin{tabular}{|c|c|}
\hline Country & Score \\
\hline Montenegro & 3.32 \\
\hline Bulgaria & 3.27 \\
\hline Macedonia, FYR & 2.92 \\
\hline Romania & 2.74 \\
\hline Croatia & 2.39 \\
\hline Serbia & 2.16 \\
\hline Bosnia and Herzegovina & 1.99 \\
\hline Albania & 1.87 \\
\hline Slovenia & 1.81 \\
\hline
\end{tabular}

Source: Authors' analysis, based on data from the website of the World Economic Forum (The Global Competitiveness Report 2013-2014).

Figure 5. Relevance of The Marshallian Cross in the analysis of affordable 
microcredits

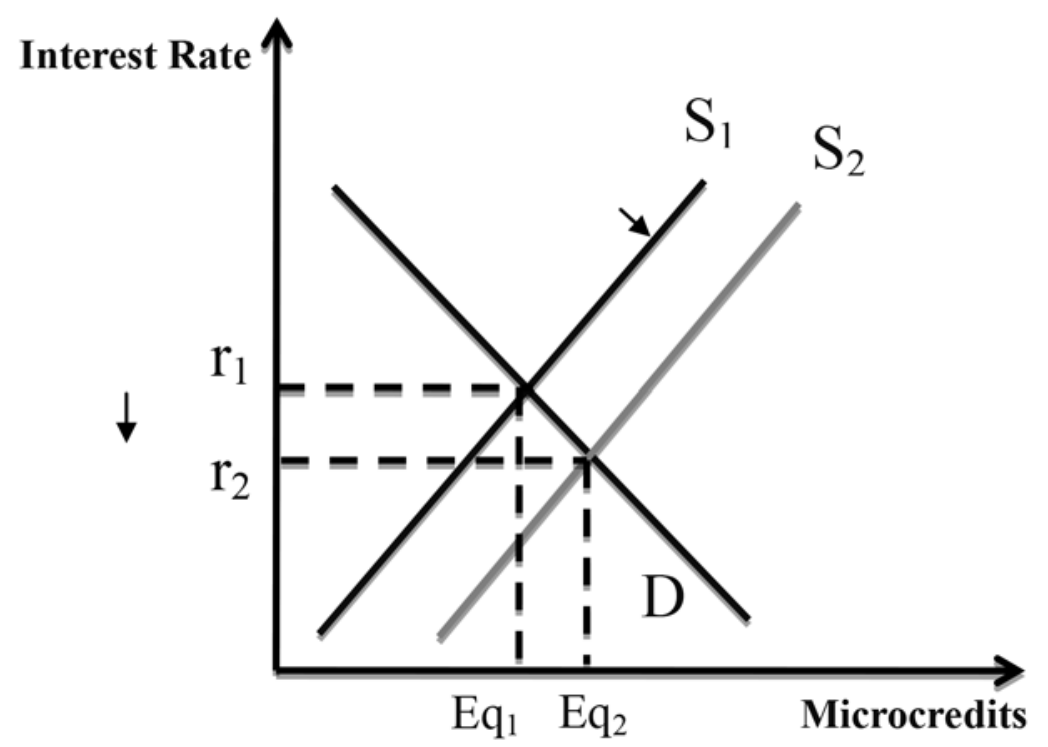

Source: Authors.

As presented in Figure 5, if the supply of microcredits shifts to the right (from the original amount $S_{1}$ to the increased level $S_{2}$ ), the equilibrium interest rate shifts down from $r_{1}$ to $r_{2}$. Loan price is not the only contracting parameter that might affect demand, and hence MFI profits and targeting. Liquidity constrained individuals may respond to maturity as well, since longer maturities reduce monthly payments and thereby improve cash flows. Therefore, maturity may be a essential policy parameter for MFIs, and may actually be more influential than price in determining demand for credit if individuals are more concerned with monthly cash flows than interest expenses (Karlan, Zinman, 2008, p. 1041). In addition to impact on the clients' households and businesses, the training could have great impact on outcomes for the MFIs. If clients' businesses improve, they are better able to repay their credits. The training also may engender goodwill, that is also leading to higher repayment rates. Credit sizes and savings volumes are ambigous: if clients learn how to manage their cash flows better, they will probably need less debt. On the other hand, the business training may lead them to expand their business, and thus also demand more financial capital (Karlan, Valdivia, 2011, p. 512). Aside from losing focus on the lending and savings services, providing 
detailed business advice may lead to higher default if the borrower then perceives the lender as partially responsible for any business changes that do not succeed (giving business advice, a lender could effectively convert the debt into equity) (Karlan, Valdivia, 2011, p. 523).

According to "The State of the Microcredit Summit Campaign Report 2012”, over the last 13 years, the number of very poor families with a microloan has grown more than 18-fold (from 7.6 million in 1997 to 137.5 million in 2010). Assuming an average of five persons per family, these 137.5 million microloans affected more than 687 million family members, which is greater than the combined populations of the European Union and Russia. "The State of the Microcredit Summit Campaign Report 2012" also highlights the number of poorest women reached. Not only have these women been the most excluded from traditional banking, but they are also the ones most likely to ensure that the increased income is used to improve the lives of their children. From 1999 to 2010, the number of poorest women reached has increased from 10.3 million to 113.1 million. Although microfinance is no longer micro in its reach, poverty still unfortunately persists very widely (The State of the Microcredit Summit Campaign Report 2012). Microfinance programs enjoy strong support across the political spectrum for their capacity to "help the poor" by "giving them a hand up, not a handout" (Woolcock, 1999, p. 17).

Table 2. Regional Differences in Access to Microfinance (at the end of 2011)

\begin{tabular}{|l|c|c|c|c|c|}
\hline REGION & $\begin{array}{c}\text { No. } \\
\text { MFIs }\end{array}$ & $\begin{array}{c}\text { No. Total } \\
\text { Clients }\end{array}$ & $\begin{array}{c}\text { No. Total } \\
\text { Women } \\
\text { Clients }\end{array}$ & $\begin{array}{c}\text { No. Poorest } \\
\text { Clients }\end{array}$ & $\begin{array}{c}\text { No. Poorest } \\
\text { Women } \\
\text { Clients }\end{array}$ \\
\hline Sub-Saharan Africa & 1,028 & $14,293,171$ & $8,016,454$ & $8,637,854$ & $5,887,337$ \\
\hline Asia and the Pacific & 1,751 & $154,606,358$ & $125,623,062$ & $110,399,508$ & $93,483,172$ \\
\hline $\begin{array}{l}\text { Latin America and the } \\
\text { Caribbean }\end{array}$ & 668 & $15,702,740$ & $10,152,799$ & $3,025,480$ & $1,958,889$ \\
\hline $\begin{array}{l}\text { Middle East and North } \\
\text { Africa }\end{array}$ & 92 & $4,899,474$ & $2,663,866$ & $2,036,891$ & $1,301,704$ \\
\hline $\begin{array}{l}\text { DEVELOPING WORLD } \\
\text { TOTALS }\end{array}$ & $\mathbf{3 , 5 3 9}$ & $\mathbf{1 8 9 , 5 0 1 , 7 4 3}$ & $\mathbf{1 4 6 , 4 5 6 , 1 8 1}$ & $\mathbf{1 2 4 , 0 9 9 , 7 3 3}$ & $\mathbf{1 0 2 , 6 3 1 , 1 0 2}$ \\
\hline $\begin{array}{l}\text { North America \& Western } \\
\text { Europe }\end{array}$ & 89 & 169,309 & 61,711 & 53,133 & 23,124 \\
\hline $\begin{array}{l}\text { Eastern Europe \& Central } \\
\text { Asia }\end{array}$ & 75 & $5,343,918$ & 252,321 & 140,861 & 95,417 \\
\hline
\end{tabular}




\begin{tabular}{|l|c|c|c|c|c|}
\hline $\begin{array}{l}\text { Industrialized World } \\
\text { Totals }\end{array}$ & 164 & $5,513,227$ & 314,032 & 193,994 & 118,541 \\
\hline GLOBAL TOTALS & 3,703 & $195,014,970$ & $146,770,213$ & $124,293,727$ & $102,749,643$ \\
\hline
\end{tabular}

Source: The State of the Microcredit Summit Campaign Report 2013

One of the great accomplishments of the economics of information has been to show how information asymmetries undermine credit markets in places where potential customers have few assets to offer as collateral (Cull, Demirgüç-Kunt, Morduch, 2007, p. 108). To reduce poverty, MFIs need to reach the poor first. In the previous table, differences in poverty outreach are observed across regions: significantly higher in Africa and Asia, than in the the Europe and Central Asia (ECA) and in the Latin America and Caribbean region (LAC). Urban clients take multiple loans primarily from lenders with more individual methodologies, while rural clients borrow from several group lenders (McIntoch, De Janvry, Sadoulet, 2005 , p. 987). The most common problem affecting neglected communities in the developing world is a lack of economic opportunity. The regional differences in poverty outreach are also due to the different poverty rates among the population of the different regions: the higher the percentage of poor population in the region, the higher the possibility of reaching poor clients by the MFIs. However, those differences do not tell the essence of the story. Not all MFIs have a poverty reduction mission: some of them do, but others may have different development objectives. Very little is known about the real poverty outreach results, because most MFIs don't yet have measurement systems ("poverty outreach bubble"). The MFIs should enhance adequate measurement systems and transparency tools.

Numerous microfinance research focuses on factors associated with the efficient delivery of loans and their effect on borrowers. In other words, many researchers are strictly focused on the financial and economic aspects of the microfinance movement. But by ignoring microfinance's cultural dimensions, including the influence of patriarchal attitudes on lending practices, the ability to make loans to the women whom microfinance was primarily intended to serve can be seriously restricted. According to some research results, women represent 70 percent of the world's poor. But still, women have traditionally been the most disadvantaged in access to credit and other financial services. Commercial banks often focus on men and formal businesses, neglecting the women who make up a large and rising segment of the informal economy. Microcredit should play an essential role in empowering women and help deliver newfound respect, independence and participation for women in their households and in their communities. Both 
governments and donors should examine possible ways of developing innovative credit programmes using intermediary channels or institutions closer to the target groups, such as co-operatives and women's group associations. Savings and credit programmes should be designed in order not to exclude women from participating. In the economy, there are a lot of trade-offs. One of these is trade-off between financial performance and outreach of microfinance institutions. To what level have microfinance institutions been successful in achieving a viable equilibrium between social goals and economic sustainability? Providing microfinance services is a highly cost business due to high transaction and information costs. The "financial" approach emphasises the importance of self-sustainability. Policymakers often presume that the poor are largely insensitive to interest rates, and then prescribe that MFIs should increase rates without fear of reducing access. Therefore, the assumption of price inelastic demand for credit by microcredit clients has fueled support for strategies where MFIs attempt to wean off subsidies by increasing interest rates (Karlan, Zinman, 2008, p. 1040). But, raising fees to very high levels does not provide better profitability, and the benefits of cost cutting diminish when serving better-off customers. On the other side, the "social" approach concentrates on using credit to help overcome poverty, primarily by providing credit with subsidised interest rates. The debate among economists comes down to the question whether subsidising interest rates is justified. The debate between these two approaches has not been concluded yet, although the most recent microfinance paradigm seems to favour the "financial" approach. The major argument to support this approach is that large-scale outreach to the poor on along-term basis cannot be guaranteed if microfinance institutions are incapable of standing on their own feet (Hermes, Lensink, 2007, p. 6-7). Statistics from the "MicroBanking Bulletin" show that financialy self-sufficient institutions working with very poor populations "had a higher average financial self-sufficiency, adjusted return on assets and adjusted return on equity than the overall averages for the 66 institutions combined" (Simanowitz, 2007, p. 62). Repayment problems intensify when there are more relatives in the same group. This confirms the hypothesis that monitoring and enforcement among relatives is less effective, since relatives may more easily collude against the programme and prolong repayment (Hermes, Lensink, 2007, p. 3). Social capital existing in traditional societies can ensure a more efficient fulfillment of loan agreements than in more developed economies with weaker social capital. Relational social capital in the form of personal trust between individuals and social homogeneity within groups has a positive effect on borrowing group performance (Cassar, Crowley, Wydick, 2007, p. 85-86). The conclusion is that institutional design and orientation matters importantly 
in considering trade-offs in microfinance. The village banks, which focus on the poorest borrowers, face the highest average costs and the highest subsidy levels. On the other side, individual based lenders earn the highest average profits, but do least well on indicators of outreach to the very poor (Cull, Demirgüç-Kunt, Morduch, 2007 , p. 31). Information frictions play an especially significant role in raising the costs of finance in emerging economies. In markets with less-well-established institutions and weaker regulations, adverse selection considerations will make it costly for firms to raise funds and may limit growth. It is assumed that information asymmetry would be especially salient in the young microfinance sector, which makes loans almost exclusively in lower developed countries. Understanding the impact of information asymmetry between borrowers and lenders is important because frictions restricting the supply of financing to these intermediaries can quickly impede the flow of credit throughout the economy (Garmaise, Natividad, 2010, p. 2561).

However, in the absence of market elements of business operations, microfinance can face a danger of "predatory" loans, with a very high interest rates. Financial experts agree that the tendency of microfinance institutions is to establish a sustainable business. However, the fact that it is more expensive to grant many small loans than one big loan, is a reason why interest rates in microfinancing are, more often than not, significantly higher than interest rates of traditional financial service providers. Lately, microcredits have been criticised for driving borrowers into a debt trap ("shark lending"). For example, a large number of Indian farmers killed themselves because they could no longer pay the high rate of interest on theirloans. Research shows that, in fact, many borrowers use the money to survive, spending it on food and medicaments. After, when the lender demands repayment, they simply take out another loan from one of the vast number of other lenders. Economists are now discussing whether Muhammad Yunus's idea carried the seeds of its own downfall or whether what was actually a great idea has fallen victim to inappropriate regulation in the financial sector.

\section{CONCLUSION}

The authors define microfinance industry as a possible solution to problems affecting national economy, assuming that microcrediting of socially sensitive groups can solve many problems of transitional societies. This is not to suggest that 
every poor person is a potential entrepreneur or that microcredit is a "panacea" able to reduce poverty everywhere and in all circumstances.

Traditional banks only grant credit to clients who can provide enough adequate collateral ("loan discrimination"). Often, low-income people cannot provide required collateral. Consequently, banks view such customers as "too risky" and refuse to grant them loans. As a result, millions of low-income people all around the world are excluded from the classic banking mechanism. Microfinance actors do believe that low-income people have an expertise and knowledge which could be used to develop a microentreprise and generate regular income. A large amount of people are positively impacted by microfinance, through the increase in wages. Also, microfinance can increase Gross Domestic Product, thus facilitating the secondary allocation of wealth.

The microcrediting system enables unemployed people to independently develop their business ideas. In this way, they work on the improvement of their own material status (increase of working motivation and feeling of satisfaction). Furthermore, at the same time, they contribute to the development of the society as a whole (productivity growth and sense of responsibility). Consequently, the competition index rises. In the situation in which the financial and economic crisis in Serbia is not calming down, microcrediting is particularly significant for retaining present and creating new jobs. Micro companies have an exceptional development potential, particularly in rural areas, where the migration of labor into cities (more job opportunities) is particularly visible. Therefore, the micro, small and medium enterprises sector is regarded as a basis for economic development. On the other side, microcrediting is important for reduction of poverty. So called "social economy", in the logic of which, the microcrediting concept fits easily, should create a balance between microeconomic stability of the family as a "nucleus of the society" and macroeconomic stability of the state, based on the principle of sustainability and uniformity. The social economy establishes a connection between individual, family and general economy.

\section{MIKROKREDITIRANJE U SLUŽBI RAZVOJA PRIVREDE SRBIJE}




\author{
Veselinović Branislav \\ Drobnjaković Maja
}

Sažetak: Takozvana ,socijalna ekonomija" predstavlja korektiv i dopunu tržišnoj ekonomiji, prevashodno, u kontekstu povećavanja moguínosti zaposljavanja, te posledično osnaživanja kompletne privrede. Značajan segment "socijalne ekonomije" jeste mikrokreditiranje. Poput ujedinjene i složne kolonije mrava koja uspeva da izgradi citav velegrad, i mikropreduzeća poseduju potencijal da ožive i uzdignu privredu, te doprinesu rastu bruto domaćeg proizvoda. Ovaj rad ima za cilj da ukaže na trenutno stanje mikrokreditne industrije u Srbiji i svetu, te da se osvrne na pojedine primere dobre prakse. Rad ima empirijski pristup, zasnovan na komparativnoj metodi.

Ključne reči: mikrokreditiranje / samozapošljavanje / privredni rast

\title{
REFERENCES
}

1. Agroinvest Holding Annual Report 2011, available on: http://www.agroinvest.rs/uploads/documents/AI_Anual_Report_2011.pdf (accessed September 24, 2012)

2. Analysis of the Application of the General Collective Agreement 2008-2011 (2011), The Serbian Association of Employers, available on: http://www. poslodavci.org.rs/images/pages/ap_oku_ser_kor.pdf (accessed September 29, 2012)

3. Berhane, G., Gardebroek, C. (2011). Does Microfinance Reduce Rural Poverty? Evidence Based on Household Panel Data from Northern Ethiopia, American Journal of Agricultural Economics, 93 (1), 43-55.

4. Brkanović, I. (2004). Is there a case for public support to self-employment programmes?, in ILO project: Social finance for support to self-employment in Serbia (Belgrade: ILO, october-december 2004.), available on: http:// 
ilo-mirror.library.cornell.edu/public/english/region/eurpro/budapest/ download/role_state_serbia_serb.pdf (accessed September 20, 2012)

5. Brkanović, I., Lalović, M., Lakić, A., Tilger, S. (2007). Micro-financial support to entrepreneurs beginners in Serbia, Entrepreneurial Society Development Centre, 3-36, available on: http://www.cezar.org.rs/publikacije/studija.pdf (accessed September 29, 2012)

6. Cassar, A., Crowley, L., Wydick, B. (2007). The Effect of Social Capital on Group Loan Repayment: Evidence from Field Experiments, The Economic Journal, 117 (517), 85-106.

7. Cull, R., Demirgüç-Kunt, A., Morduch, J. (2007). Financial Performance and Outreach: A Global Analysis of Leading Microbanks, The Economic Journal, 117 (517), 107-133.

8. Drobnjaković, M. (2012). Rural Banking as a Means of Prevention of Rural Depopulation, $1^{\text {st }}$ International Scientific Conference Population: Development/Crisis (168-179), Faculty of Technical Sciences in Novi Sad.

9. European Platform against Poverty and Social Exclusion (2010). Youth with Disabilities Forum Serbia, available on: http://fmi.rs/wp-content/ uploads/2012/12/Evropska-platforma-za-borbu-protiv-siromastva.pdf (accessed September 20, 2012)

10. Fourth Newsletter on Social Inclusion in Serbia (2010), available on: http:// www.inkluzija.gov.rs/wp-content/uploads/2010/03/Cetvrti-bilten-o-socijalnom-ukljucivanju-u-Srbiji1.pdf (accessed September 19, 2012)

11. Frankiewicz, C., Churchill, C. (2011). Making microfinance work, International Labour Office, Geneva.

12. Garmaise, M., Natividad, G. (2010). Information, the Cost of Credit, and Operational Efficiency: An Empirical Study of Microfinance, The Review of Financial Studies, 23 (6), 2560-2590.

13. Hermes, N., Lensink, R. (2007). The Empirics of Microfinance: What Do We Know?, The Economic Journal, 117 (517), 1-10.

14. Hutchinson, J., Guttentag, M., Chen, Y., Mo, K. (2012). Youth Entrepreneurship in Serbia - Constraintsand Opportunities, George Washington University.

15. Janićijević, N., Petković, G. (2011). Microfinance in Serbia, in Confronting Microfinance: Undermining Sustainable Development, edited by Milford Bateman, Quicksilver Drive, Sterling, 125-153.

16. Karlan, D., Valdivia, M. (2011). Teaching Entrepreneurship: Impact of Business Training on Microfinance Clients and Institutions, The Review of Economics and Statistics, 93 (2), 510-527. 
17. Karlan, D., Zinman, J. (2008). Credit Elasticities in Less-Developed Economies: Implications for Microfinance, The American Economic Review, 98 (3), 1040-1068.

18. Labour Force Survey - Serbia (2012), available on: http://pod2.stat.gov.rs/ ObjavljenePublikacije/G2013/pdfE/G20135564.pdf (accessed May 20, 2013)

19. Mahmudul, A., Islam Rafiqul, M. (2012). The limitations of microcredit for promoting microenterprises in Bangladesh, Economic Annals, 57 (192), 4153.

20. McIntosh, C., De Janvry, A., Sadoulet, E. (2005). How Rising Competition among Microfinance Institutions Affects Incumbent Lenders, The Economic Journal, 115 (506), 987-1004.

21. MSME Dialogue Series (2004). United Nations Development Programme, available on: http://europeandcis.undp.org/files/uploads/PSD/DIalogue\%20Series/MSME\%20Reader.pdf (accessed September 20, 2012)

22. Simanowitz, A. (2007). Achieving Poverty Outreach, Impact and Sustainability: Managing Trade-Offs in Microfinance, in Microfinance and Public Policy - Outreach, Performance and Efficiency, Edited by Bernd Balkenhol, Palgrave Macmillan, Basingstoke, 60-69.

23. The Europe 2020 Strategy (2012). The Community of Practice on Inclusive Entrepreneurship, available on: http://cop-ie.eu/sites/default/files/COPIE_Mid_Term_Event_EU_Maes.pdf (accessed September 29, 2012)

24. The Global Competitiveness Report 2013-2014 (data platform), World Economic Forum (accessed January 29, 2014)

25. The State of the Microcredit Summit Campaign Report 2012, available on: http://www.microcreditsummit.org/pubs/reports/socr/2012/WEB_ SOCR-2012_English.pdf (accessed September 24, 2012)

26. The Statistical Office of the Republic of Serbia (2012). available on: http:// webrzs.stat.gov.rs/WebSite/Public/PageView.aspx?pKey=2 (accessed September 28, 2012)

27. Veselinović, B., Ševarlić, M., Nikolić, M. (2007). Long term-trends in Serbian Agriculture, Trends in the Development of European Agriculture (617622), Timisoara, The Faculty of Agriculture of the Agricultural and Veterinary University of the Banat.

28. Woolcock, M. (1999). Learning from Failures in Microfinance: What Unsuccessful Cases Tell Us about How Group-Based Programs Work, The American Journal of Economics and Sociology, 58 (1), 17-42. 